\title{
The Motivation of High School Students by Achievement Goals
}

\author{
Marcelo Simões Mendes - Universidade Paulista, Campinas, Brasil
}

\begin{abstract}
The present study aimed to identify, describe and analyze the achievement goals of 207 high school students in a city in São Paulo state. The instruments were the Characterization Questionnaire and Achievement Goals Questionnaire. The results indicate a major tendency to adopt the mastery-approach goal, where the student engages the activity with the purpose of developing their skills. The second more adopted goal was performance-avoidance goal, in which students tend to want to show their skills to others not to appear incompetent for them. These results above may be related to a great intension of students in completing the high school and enter the University, results also found in this study. Comprehend Achievement Goals can contribute to understanding the quality of motivation that the students apply in their activities.

Key-words: Achievement Motivation; Educational Objectives; High School Students.
\end{abstract}

A Motivação de Estudantes do Ensino Médio pelas Metas de Realização

\begin{abstract}
Resumo
O presente estudo buscou identificar, descrever e analisar as metas de realização de 207 estudantes do Ensino Médio de uma cidade paulista. Os instrumentos utilizados foram o Questionário de Caracterização e o Questionário de Metas de Realização. Como resultados foi observada maior tendência à adoção da meta aprender-aproximação, caracterizada por alunos que se engajam na atividade com o intuito de desenvolver suas próprias habilidades. A segunda meta mais adotada foi a performance-evitação, cujas características estão presentes no aluno que tende a querer mostrar suas habilidades a terceiros com o objetivo de não se apresentar como incompetente para outros. Estes resultados supracitados podem estar relacionados pela forte intenção dos alunos em concluírem o Ensino Médio e ingressarem no Ensino Superior, resultados também encontrados no presente estudo. Compreender as Metas de Realização pode colaborar para o entendimento da qualidade da motivação que os estudantes empregam nas atividades.

Palavras-chave: Motivo de Realização; Objetivos Educacionais; Estudantes de Ensino Médio.
\end{abstract}

La Motivación de los Estudiantes de la Escuela Secundaria por las Metas de Realización

\begin{abstract}
Resumen
El presente estudio busco identificar, describir e analizar las metas de realización de 207 estudiantes de escuela secundaria en una ciudad de la provincia de São Paulo. Los instrumentos eran el Cuestionario de Caracterización y el Cuestionario de Metas de Realización. Los resultados indican una mayor tendencia a adoptar la meta enfoque de aprendizaje, donde el estudiante se involucra en la actividad con el propósito de desarrollar sus propias habilidades. La segunda meta más adoptada fue rendimiento-evitación, cuyos estudiantes tienden a querer demonstrar sus habilidades a los demás a fin de no mostrarse como incompetente para otros. Estos resultados arriba pueden estar relacionados con la fuerte intensión de los estudiantes concluyen la escuela secundaria y ingresaren en la educación superior, resultados también encontrados en este estudio. Entender las metas de realización puede contribuir para la comprensión de la calidad de la motivación que el estudiante emplea en sus actividades. Palabras clave: Motivo de Realización; Objetivos Educacionales; Estudiantes de la $9^{\mathrm{a}}$ e $12^{\mathrm{a}}$ series;
\end{abstract}

\section{Introduction}

the issues discussed about Basic Education in Brazil comprise a challenging scenario for professionals involved in this area of knowledge and practice, encompassing professionals from political scientists and academic researchers to those who work directly in the school context daily. The numerous challenges related to the formal educational environment may present themselves differently, considering, for example, the characteristics of each education stage. Thus, high school needs to be understood by its contextual characteristics and its specificities, so the understanding of the phenomena that involve this stage is achieved with greater property in its arguments.

High school has a transitional characteristic because it is between the last stage of Basic Education and the one before higher education. This attribute must be considered since it can influence directly and / or indirectly various phenomena and processes inherent to the school environment, such as motivation to learn, students engagement in academic activities, the purposes or goals to complete this level of education. Another characteristic is about the significant need 
of adolescents to be approved by the social groups which they participate, and this factor is directly correlated to the motivation quality and investment of these young people.

In this sense, it is relevant to understand what objectives or goals the students show in High School so that, in this way, we can understand the behaviors as well as the motivational aspects involved in adopting these goals. For this purpose, the present study is supported in the construct from the field of student motivation denominated as Achievement Goals.

\section{High School in Brazil}

Regarding specifically high school, the proposal of this study is to characterize this stage of Basic Education. At this moment, the aim is to discuss issues ranging from the purposes that this stage of education proposes, to the problems found in the classroom environment, including motivation issues, or maybe demotivation.

According to Krawczyk (2009), high school does not have a defined identity in order to understand clearly the purposes of this level of education. For this author, it is an open question whether this level would serve as a preparation for the job market, to admission in College, to continue the complete formation of the student or as a purpose that includes these three goals. Continuing this discussion, Castro (2008) argues that when establishing a standard education that aims to meet all the students' needs in general without considering the specificities of each individual, in practice what happens is that few of these needs are met. The author also discusses the current models in other countries, such as the American model in which there is a bigger opening when choosing the subjects, allowing the student to compose a resume better linked to their interests and choices.

The Articles 35 and 36 of the Education Law (Lei de Diretrizes e Bases/LDB - 9394/96) are designated specifically to high school, and in these Articles the curriculum emphasis is oriented to skills and not to the content. According to Mello (1998), this curriculum does not have the classical school discipline as a reference anymore, but the capabilities that each discipline can develop in students.

Even though high school purposes and objectives are not so clearly defined, it is suitable to consider the strong influence that being admitted into higher education presents in this educational stage. In the study developed by Amparo, Galvão, Cardenas and Koller
(2008), in which 852 young people from high school in public schools of the Federal District with ages ranging from 13 and 27 years of low socioeconomic status participated, among other variables, the perspectives of young people in relation to school and continuing their studies were verified. It was found that $90.7 \%$ of young people agree that their studies are important for their lives and that $94 \%$ indicated that studying is important both for their future and to enter higher education.

In the study by Machado (2005), attended by 30 students (17 male and 13 female) of high school in a public school in the city of Campinas, São Paulo, aged from 16 to 19 years approximately and mediumlow socioeconomic level, the aim was to examine the perceptions of participants about the various dimensions of school environment, relating them to students personal development and motivation to learn. In this study, less than half of students considered themselves motivated to go to school, but when asked if they would choose to continue their studies, all reported so.

Related to the motivation of students to continue their studies presented in Machado's work (2005), the study by Franco and Novaes (2001), attended by 481 students from 10 state schools located in São Paulo city that offer exclusively high school, students justified the importance that Education had in their lives. In this study, that aimed to investigate the social representations of these young students, was identified that the students attributed to school and education the only way to get a better social status and more qualified jobs, and they expressed their desire to continue their studies.

Indeed, high school in Brazil is seen by many people as a transitional stage in young students lives and the College entrance examination acquires an importance that deserves at least to be discussed under some point of view. In this sense, the study of Fagundes, Aquino and Paula (2010) aimed to understand the perception of stress in graduating students of the last year of high school. The study included 20 students of both sexes, from a private and a public school in the city of Lavras (MG), with ages ranging from 17 to 19 years. The results were classified into three categories. The first category relates to the consequences and / or reflections of stress in which were identified insomnia, discouragement, learning difficulties and impatience. The second category refers to the social and family expectations. In this category, the main stressor of participants regards to how these young people see themselves regarding the preparations for the College entrance exam, followed by how the family deals with this moment and the 
expectation created by the family for the professional future of these young people. Finally, the third and last category relates to the strategies used by the participants to deal with stress. In this category the answers were found on three levels: how these participants deal with stressful situations, with the expectations and what they do to minimize such stress situations.

In the study by Rodrigues and Pelisoli (2008) the objective was to verify the prevalence of anxiety indicators in students from College entrance exam courses in the city of Porto Alegre - Rio Grande do Sul. Hutz and Bardagi (2006) state that the professional choice made during adolescence can have a motivational role on the teenager, making them study and set a plan to succeed in the college entrance exam. On the other hand, there may be an anxiogenic factor due to the fact that to choose a profession it is necessary to know the field of work, the labor market, routine, earnings and all the other features that come with professional life. These authors also discuss the role of the family in this life stage, and report that the objective and subjective negotiations involving all the aspects that are part of this process occur within the family.

In the study of Rodrigues and Pelisoli (2008), 1.046 students participated, being $37.3 \%$ male and $62.7 \%$ female and the average age was 18 years (SD 2.71). The results showed that $43.6 \%$ presented minimal level of anxiety, $32.8 \%$ average level of anxiety, $17.7 \%$ moderate and $5.8 \%$ severe level of anxiety. Two other variables were also investigated: the feeling of obligation to take the college entrance exam and the fact of considering this exam decisive in the teenager's life. Among the students who felt obliged to take the college entrance examination, it was found that they presented significantly more anxiety compared to those who did not feel obliged to conduct such an examination. Students who considered the entrance exam decisive in their lives also had a higher level of anxiety than students who did not. Also according to Rodrigues and Pelisoli (2008, p. 173), "while preparing for the entrance exam, the teenager faces, besides the uncertainties and insecurities inherent to their developmental condition, the expectation of family, friend and society for their approval."

In a great nationwide study carried in high schools by Abramovay and Castro (2003), attended by over 50 thousand students and seven thousand teachers from several capitals of Brazil, the question of admission in higher education and the importance given to college entrance examination became clear both from the students and teachers perspective. When students were asked about the purpose of high school, they said it was a preparation for the entrance exam for higher education. For these authors, what motivates the students to graduate from high school is not acquiring the diploma, but being approved in the entrance exam to go into higher education as a way to get a social distinction. Albeit on a smaller scale, teachers also reported that the main purpose of high school is to prepare students for the entrance exam.

Considering the data presented above, the importance given to the college entrance examination and admission to higher education is evident. However, it is possible to notice a contradictory scenario since on one hand high school students show a tendency for further study, on the other hand, they are somehow unmotivated. For a better understanding of the motivational variable in the school context, the implications of motivation in teaching and learning process will be presented below, as well as the goals that students set in order to accomplish the schoolwork and their achievements.

\section{The Motivation and the Construct of Acbievement Goals}

There have been discussions on the role of motivation in the educational environment covering both macro dimensions - for example, public policies - as well as the classroom environment. To Bzuneck (2009a), motivation is what moves a person, what puts them into action or changes their course. Motivation has been understood either as a psychological factor, or a combination of factors, and as a process. There is a consensus among authors about the dynamics of these factors, leading to a choice, a search that starts a directed behavior to a particular purpose (Bzuneck, 2009a; Costa \& Boruchovitch, 2006).

If on one hand the motivation is associated with students' engagement processes in learning situations, on the other hand, Bzuneck (2009a) states that the lack of motivation represents a decline of quality personal investment in learning tasks. For the author, this decrease can configure an educational situation that prevents the formation of more competent individuals to exercise citizenship and to develop as individuals.

Boruchovitch and Bzuneck (2010) reported that most Brazilian researches in the field of motivation have been working with specific motivational constructs, and it is possible to notice two segments for these investigations. The first is guided by theoretical frameworks in order to identify in students the presence of motivation in a greater or lesser degree, in other words, the quantitative characteristics of the motivational variable. 
The second segment of studies comprises the qualitative aspects of motivation, trying to establish relations with other intrapersonal variables or even the context in which a phenomenon is investigated. In the latter one, in contrast to assessing the level of student motivation, the research process opens space for, among other aspects, students to give meaning and significance for their own motivation.

Not only on the national scenario, but within the theoretical models adopted worldwide to investigate the motivation in the school context, the construct of Achievement Goals is emphasized. Zeronini and Santos (2010) point out that this construct has been bringing major contributions to the understanding of the motivational factors that influence student behavior, as this construct seeks to explain the motivation focusing on the qualitative aspect of student engagement in the learning process.

To Bzuneck (2009b), among the most powerful motivators of human behavior are the goals that one sets out to achieve. Based on the considerations made by some authors (Bzuneck, 2009b; Elliot \& McGregor, 2001; Elliot, Mcgregor, \& Gable, 1999; Gouveia Diniz, Santos, Gouveia, \& Cavalcanti, 2008), the achievement goals consist on the purpose or cognitive-dynamic focus of engagement in a task so that the orientation to a particular achievement goal works as a framework that allows the individual to interpret and experience the realization of contexts, leading to behavioral decisions and affective reactions. In other words, an achievement goal consists on the purpose that leads a student on engaging on a task, so depending on the type of achievement goal by which a student is guided, it is possible to identify how they behave and direct their actions to fulfill their goals. In this perspective, to studying the construct of achievement goals is important, since goals are essential to explain the behavior of individuals in performing tasks, such as those typical of the school context (Gouveia Diniz, Santos, Gouveia, \& Cavalcanti, 2008).

According to Elliot (2005), the construct of achievement goals was developed from an independent, but at the same time collaborative work of Carol Ames, Carol Dweck, Marty Maehr and John Nicholls. In late 1977, these researchers discussed in several seminars questions about the motivation for achievement. Elliot (2005) reports that in a number of studies Dweck and colleagues (Diener \& Dweck, 1978, 1980; Dweck, 1975; Dweck \& Reppucci, 1973) showed that children with the same capabilities responded differently in performing tasks. Some children presented adaptative responses ${ }^{1} \mathrm{e}$ when facing failure in a given task, attributed the cause to their insufficient effort.Still, they continued feeling well and had a positive result expectations, which sustained or increased their persistence and performance, seeking subsequent challenges. Other children showed less adaptative, and were characterized for attributing the cause of failure to insufficient capacity and negative result expectations, reducing the persistence and performance, and avoiding subsequent challenges. Thus, two types of targets established by children were identified: 1) performance goal, in which the purpose is to demonstrate competence for other people; 2) mastery goal, in which the purpose is to develop the skill.

Continuing the issue of adaptative and maladaptative patterns of learning and performance goal, Dweck and Leggett (1988) described a research model based on behavior patterns in terms of underlying psychological processes. For this purpose, two patterns were identified: 1) the least adaptative, characterized by the avoidance of challenge and deterioration of performance when facing obstacles; 2) the most adaptative, involving the search for challenging tasks and maintenance of effective effort in situations involving mistakes. Therefore, the performance goal was associated with less adaptative standards and the mastery goal with more adaptative patterns (Elliot \& Dweck, 1988; Farrell \& Dweck, 1985; Leggett \& Dweck 1986 cited by Dweck \& Leggett, 1988).

Conceptually, Ames and Archer (1988) report that when a person is guided by the performance goal, their concern is in being judged capable and being able to show they are clearly capable through achieved success, surpassing others by the success accomplished with little effort. The adoption of an orientation by mastery goal involves developing new skills. In this perspective, success is conceived and achieved through the effort expended.

Students who adopt the mastery goal are interested in acquiring new skills and improve their knowledge, even if they commit some mistakes. On the other hand, students who adopt the achievement goal are usually interested in obtaining positive assessment on their capacities and avoid negative evaluations. In summary, the mastery goal involves the pursuit of development

\footnotetext{
${ }^{1}$ They are connected to the achievement and activity engagement standards in more optimal levels in which representations dialogue with a learning and more lasting and meaningful development. A contrary direction to such levels of optimization refers to less adaptative responses.
} 
and skills improvement and the performance goal implies on demonstrating competence to others (Valle et al., 2003).

Afterwards, Elliot and Church (1997) and Elliot and Harachiewickz (1996) proposed a trichotomous structural model in which the concept of mastery goal remained the same and the concept of performance goal was bifurcated into performance-approach goal and performance-avoidance goal. According to Shim, Ryan and Anderson (2008), the performance-approach goal focuses on demonstrating high competence and positive judgment by others. The performance-avoidance goal focuses on avoiding demonstrating incompetence and preventing negative judgments of others.

A few years after the presentation of the trichotomous model, Elliot and McGregor (2001) proposed a structure model $2 \times 2$ of achievement goals, in which there is a bifurcation in the mastery goal concept, creating the mastery-approach goal and the masteryavoidance goal. The mastery-avoidance goal is classified as being more negative than the mastery-approach goal and more positive than performance-approach goal. A key point to differentiate the mastery-avoidance goal from the performance-avoidance goal is that on performance-avoidance goal the focus is to perform on activities avoiding negative judgement of others, and in mastery-avoidance goal the engagement in activities seeks to avoid negative judgements by themselves. Some features are related to the mastery-avoidance goal, such as fear of failure, low self-determination, low perception of engagement in class, etc. This type of goal can have some consequences, such as disorganization to study, anxiety, worry, etc. (Elliot \& McGregor, 2001).

The construct of Achievement Goals has a close connection with the concept of competence. From this point of view, in the mastery-approach goal the competence is defined in absolute / intrapersonal terms, in other words, the parameter to define the competence lies on the subject itself and the evaluation of this competence is positive (Elliot \& McGregor, 2001). To Gouveia Diniz, Santos, Gouveia and Cavalcanti (2008), this means that the individual seeks to understand the task or to improve their own knowledge and assess their competence in terms of positive and desirable possibilities (in which the individual wants to get closer to success). In mastery-avoidance goal the competence is defined in absolute / intrapersonal terms and the evaluation is negative (to avoid failure). In the performance-approach goal the competence is defined in normative terms, that is from third parties and the evaluation of this is performed positively. In Gouveia Diniz, Santos, Gouveia and Cavalcanti (2008) interpretation, the individual who adopts this goal strives to do better than the others and evaluate their skills positively. In performance-avoidance goal, the competence is also defined in normative terms, but negatively evaluated.

In the study of Wigfield and Cambria (2010), the authors presented a review of the main constructs that investigate the students' purposes to do different activities: achievements values, orientation goals and interests. It has been found that most authors report that the mastery-approach goal brings more benefits to students. However, some argue that performanceapproach goal can also benefit the students. In this sense, even if the performance-approach goal is less adaptative in terms of subsequent motivation, affections, strategy and performance use, in some situations, especifically when associated with mastery goal, performance-approach goal may not be as maladaptative and may result in a better performance and achievement (Pintrich, 2000). In other words, the interaction of two types of goals, called the multiple goals, can lead to positive results. This is what Pintrich (2000) reports, suggesting that there may be multiple paths or strategies development from the combination of the two goals.

Considering all the above, the present study proposes to identify, describe and analyze the achievement goals of high school students. Fulfilling this purpose, methodological considerations used in this study will be presented, followed by the presentation of the results and the discussions.

\section{Method}

\section{Participants}

The study included 207 high school students from four public schools in a large city in São Paulo State, Brazil. The average age was 16.05 years $(\mathrm{SD}=1.35)$. Schools attended by the participants were located in peripheral areas of the city and $98.07 \%$ of students who participated in this study were from public schools.

For the period in which the participants attended classes, $36.71 \%$ of participants attended the morning period, $20.29 \%$ the afternoon and $43 \%$ of participants attended the evening period. Referring to the distribution of participants by grade, $37.68 \%$ of the students were in the first year of high school, $38.65 \%$ in the second, and $23,67 \%$ belonged to the third grade.

When participants were asked if they meant to finish high school, only one student reported that he 
had no intention. When asked if they intended to go to college, $96.5 \%$ said yes and only $3.5 \%$ indicated that they had no intention to attend higher education.

\section{Instruments}

To meet the objectives proposed in this study, the instruments used were the Characterization Questionnaire and the Achievement Goals Questionnaire (AGQ):

1. Characterization Questionnaire: in order to characterize the sample of this study this instrument sought to investigate some relevant data: gender, age, type of school attended (public and / or private) in elementary school, type of primary education (conventional or supplementary), grade retention (if any, which grade was it), grade, period of day, parents educational background, work status, intention to complete high school and enter the higher education.

2. Achievement Goals Questionnaire (AGQ). This instrument was originally elaborated by Elliot and McGregor (2001). It consisted of 12 items, and later it was adapted and validated by Gouveia, Diniz, Santos, Gouveia and Cavalcanti (2008) for the Brazilian reality - specifically for high school. The items are equally distributed in four achievement goals that were theoretically derived: Mastery-approach goal - this goal the focuses on developing capacities and skills (for example, I wish to fully master the subject presented in class); Masteryavoidance goal - the goal is to learn not to show incompetent for themselves (for example, I am sometimes fearful (afraid) of not being able to understand the content of the classes as I would like); Performanceapproach goal - in this type of achievement goal the aim is to work to prove themselves more competent than the other (for example, My goal in this classroom is getting better grades than most students); Performance-avoidance goal - in this goal the individual seeks to demonstrate competence to not be judged negatively by others (for example, My goal is to avoid having poor performance in class). The items are answered in Likert 7-point scale, with the following extremes: $1=$ Does not describe me at all and $7=$ Describes me completely.

In the current study, the internal consistency was verified (Cronbach's $\alpha$ ) to measure the reliability of AGQ. In this verification the mastery-approach goal
Cronbach's alpha was 0.715 and the performanceapproach's was 0.739 . In the mastery-avoidance goal the Cronbach's alpha was 0.623 and in the performanceavoidance goal the consistency was 0.579 .

\section{Procedures}

Since this is a study involving humans, it was evaluated by the Research Ethics Committee of UNICAMP, whose approval was granted in the opinion $\mathrm{n}^{\circ}$ 1185/2009 CAAE: 0912.0.146.000-09. Subsequently the contact with the Regional Education Board was done so as to obtain the application grant for this research. Properly accepted, the schools belonging to the region of such Teaching Board were contacted for the initial explanation of the purposes of this study, as well as the cautions and ethical criteria in which this study has its foundations.

After this step, the data collection procedure with the participants was initiated. For this purpose, a date for data collection with each school was scheduled without compromising school activities. The day before the data collection in each school, the researchers explained to the students the objectives of the research, cautions and ethical criteria and those who expressed interest in participating in the study received the Informed Consent Form. Thus, such students were told that they could only participate in this research if they brought at the time of application of the instruments, the term filled and signed by them and by their parents, in the case of underage students. After this stage, the process of analysis and processing of data began so that the results could be interpreted and discussed.

\section{Results and Discussion}

Considering the aim of this study, which was to identify, describe and analyze high school students' achievement goals, the results will be presented and relevant discussions of such data will be made. Before presenting the scores for each achievement goal it is important to point out that the scores of the four achievement goals from the AGQ presented significant differences among them, as shown in Table $1^{2}$.

Initially, the results will be presented in order to display each achievement goal followed by the AGQ items that compose them According to Table 2, the mastery-approach goal was the one with higher average

\footnotetext{
${ }^{2}$ The level of significance indicated in Table 1 refers to the four achievement goals from AGQ used in this study.
}

Psico-USF, Bragança Paulista, v. 21, n. 2, p. 353-366, mai./ago. 2016 
Table 1

Comparative Analysis between the Scores of the AGQ Achievement Goals

\begin{tabular}{lccccccc}
\hline Type of Achievement Goal & $\mathrm{N}$ & AVERAGE & S.D. & MIN & MEDIAN & MAX & $*$ P \\
\hline Mastery-approach Goal & 207 & 5.98 & 1.06 & 1.67 & 6.33 & 7.0 & $\mathrm{p}<0.001$ \\
Mastery-avoidance Goal & 206 & 5.06 & 1.36 & 1.0 & 5.33 & 7.0 & \\
Performance-approach Goal & 205 & 4.79 & 1.52 & 1.0 & 5.0 & 7.0 & \\
Performance-avoidance Goal & 207 & 5.44 & 1.18 & 1.67 & 5.66 & 7.0 & \\
\hline
\end{tabular}

Nota. $*$ P is related to the Wilcoxon test for related samples to compare the scores of the four AGQ the Achievement Goals.

(5.98). As to the items, it was observed that the highest score was from item six (It is important for me to understand as much as possible the content of the subjects), in which the average score was between 5.06 and 7.00, followed by item nine (I want to learn as much as possible in class), in which the average score was between 4.86 and 7.00. The average variation found in item six was higher than the one observed in the mastery-approach goal (4.92 to 7.00).

It is important to infer some considerations about the possible reasons for mastery-approach goal being the most adopted or that showed the highest tendency to orientation ${ }^{3}$ and that even denotes certain limitations found in this study. The high tendency of adopting mastery-approach goal can, in part, be characterized by biased self-presentation present in the self-report questionnaires, in which some students choose answers that represent a better image of themselves, although this does not correspond to their reality. This is justified by the fact that the items for this achievement goal tend to reveal a student concerned about teaching and learning process and engaged in their schoolwork.

Still regarding mastery-approach goal, although some studies (Abramovay \& Castro, 2003; Amparo, Galvão, Cardenas, \& Koller, 2008; Machado, 2005) indicate a low level of motivation on the part of high school students, they also have a strong desire to continue their studies and attribute value to the importance of continuing studying. This data converges with the data found in the present study in which almost all students

\footnotetext{
${ }^{3}$ The nomenclature orientation tendency or adoption is justified by the fact that as much as the predominant target is identified through AGQ, the same student can not strictly guide on the characteristics of a single goal and may even be guided from the characteristics of various achievement goals. This study will use this nomenclature or even the adoption of one achievement goal.
}

testified they intended to complete high school. Such inference is better supported through item six, which had the highest average score of all from AGQ.

Especially in Brazilian high school, the mastery-approach goal seems to meet the premises of the Education Law (Lei de Diretrizes e Bases/LDB9394/96), once Articles 35 and 36 indicate that the curriculum of this stage of basic education must emphasize skills and not content. In the masteryapproach goal the aim is to develop skills that enable students to better engage in activities and contribute to their self-fulfillment. For Mello (1998), this means that this curriculum seeks to develop the skills and personal, intellectual and social competencies, what makes such principles engaged to the new guidelines for high school in Brazil.

The notes of the previous paragraph are related to the mastery-approach goal and denote how much the sample of this study tends to be 'aligned' to LDB parameters. However, other interpretations may be attributed to the fact that this goal has presented the highest score. Once participants can show a greater tendency to a more adaptative motivation through the high score presented in the mastery-approach goal, it is also necessary to question what parameters were used for this adoption.

As pointed out previously, in this study and in others (Abramovay \& Castro, 2003; Amparo, Galvão, Cardenas, \& Koller, 2008; Machado, 2005), students showed a great motivation to graduate from high school and to enroll in higher education, since almost all participants showed this intention. Thus, does having the graduation from high school and the approval into higher education as main purposes translates such an adaptative motivation? Does the engagement of students fulfills the so-called purposes of high school or, in other words, does it prepare the student for the labor market, social practice and personal fulfillment? 
Table 2

Overall descriptive analysis of the mastery-approach goal and AGQ items that make up this type of achievement goal

\begin{tabular}{|c|c|c|c|c|c|c|c|c|}
\hline Achievement Goals and Items & $\mathrm{N}$ & AVERAGE & S.D. & MIN & Q1 & MEDIAN & Q3 & MAX \\
\hline Mastery- approach Goal & 207 & 5.98 & 1.06 & 1.67 & 5.67 & 6.33 & 6.67 & 7.00 \\
\hline $\begin{array}{l}3 \text { - I wish to fully master the } \\
\text { subject presented in class }\end{array}$ & 207 & 5.59 & 1.54 & 1.00 & 5.00 & 6.00 & 7.00 & 7.00 \\
\hline $\begin{array}{l}6-\text { It is important for me to } \\
\text { understand as much as possible } \\
\text { the content of the subjects }\end{array}$ & 207 & 6.26 & 1.20 & 1.00 & 6.00 & 7.00 & 7.00 & 7.00 \\
\hline $\begin{array}{l}9-\mathrm{I} \text { want to learn as much as } \\
\text { possible in class. }\end{array}$ & 207 & 6.09 & 1.23 & 1.00 & 6.00 & 6.00 & 7.00 & 7.00 \\
\hline
\end{tabular}

These observations come together with the fact that the second more adopted achievement goal was the performance-avoidance goal, owing to the highly competitive scenario for approval into higher education, the need to show competence to the others can acquire a great importance. Regarding this goal, in which the average variation ranged from 4.26 to 6.64 , it is possible to observe (as shown in Table 3) that among the items of this type of achievement goal, the one with the highest average (6.08) and the smallest average variation (4.69 and 7.00) was item 11 (I want to avoid to do badly (have poor performance) in the classroom). Nevertheless, the item that showed a lower average score (4.35) and a higher average fluctuation in relation to other items (2.39 to 6.31) was item four (What motivates me in the classroom is my fear of having poor performance).

In what concerns the performance goal, it is possible to consider the reflections of Ames and Archer (1988), who reported that when a person guides themselves through a performance goal, their concern is to receive an evaluation from other people that they are capable and skilled, evidenced by the success achieved, surpassing others, or by the success accomplished with little effort. To sum up, individuals who are guided by performance goal seek to demonstrate competence to others (Valle et al., 2003).

When analyzing the notes above and the participants' strong intention to complete high school and enroll in higher education, it is possible to infer the relationship between the college entrance exam and the intention of showing competent to others or avoiding being misjudged. Item 11 (I want to avoid to do badly (have poor performance) in the classroom), with the highest average score, expresses how much the external judgment is presented as a significant characteristic present in students of this level of education.

Indeed, the importance that access to higher education has for high school students is evident. However, excessive focus on such access by college

Table 3

Overall descriptive analysis of the performance-avoidance goal and AGQ items that make up this type of achievement goal

\begin{tabular}{lcccccccc}
\hline Achievement Goals and Items & $\mathrm{N}$ & AVERAGE & S.D. & MIN & Q1 & MEDIAN & Q3 & MAX \\
\hline Performance-avoidance Goal & 207 & 5.45 & 1.19 & 1.67 & 4.67 & 5.67 & 6.33 & 7.00 \\
$\begin{array}{l}\text { 04 - What motivates me in the } \\
\text { classroom is my fear of having } \\
\text { poor performance }\end{array}$ & 207 & 4.35 & 1.96 & 1.00 & 3.00 & 5.00 & 6.00 & 7.00 \\
$\begin{array}{l}\text { 08 - My goal is to avoid having } \\
\text { poor performance in class }\end{array}$ & 207 & 5.91 & 1.45 & 1.00 & 5.00 & 6.00 & 7.00 & 7.00 \\
$\begin{array}{l}11-\text { I want to avoid to do } \\
\text { badly (have poor performance) } \\
\text { in the classroom }\end{array}$ & 207 & 6.08 & 1.39 & 1.00 & 6.00 & 7.00 & 7.00 & 7.00 \\
\hline
\end{tabular}


entrance examination can produce several consequences, not always adaptative. As shown previously, some studies, such as Fagundes, Aquino and Paula (2010), have shown how the preparation for the university entrance exam produces various anxiogenic factors, for instance, the expectations placed by the family in the student to succeed in this examination. In this direction, Rodrigues and Pelisoli (2008) point out that, in addition to the uncertainties and insecurities of the choice of degree course, the family, friends and society's expectations for approval in the college entrance examination is strongly present.

Thus, considering the expectations and social pressures, directly and indirectly, for the high school students to get a good qualification in the college entrance examination, it is possible to infer that performanceavoidance goal has the second highest average among the achievement goals verified in this study. Such proposition is justified by the fact that high school students present a need to prove themselves capable and competent to others (family, friends and society in general).

Once again a reflection on the quality of the motivation that drives attitudes like this should be made. On what parameters students build their motivation to present an intense need to show competency to third parties and avoid receiving a bad judgment on their performance? Although the college entrance examination can be closely related with the motivational characteristics involved in this achievement goal, especially for implying a highly competitive atmosphere, this is not the only justification for this result. The need for social approval in adolescence is also an aspect to be taken into account to explain the motivational quality involved in performance-avoidance goal, since this characteristic prevails at this stage of life. Thus, analyzing the quality of the motivation involved in this and other achievement goals can help the teacher to understand some aspects involved in student motivation, especially because, as Abramovay and Castro (2003) point out, for almost all the teachers the ultimate goal of high school is preparing for the college entrance examination and enrollment in higher education.

Continuing the presentation of data, the mastery-avoidance goal was the one that showed the third highest average among achievement goals on this study (5.06). In this achievement goal the item that had the highest average score (5.40) and the lowest range (3.73 to 7.00 ) was item 12 (I worry that I cannot learn all that I could in the classroom). On the other hand the item that showed the lowest mean score (4.61) and the widest range (2.52 to 6.69) was item two (I am sometimes fearful (afraid) of not being able to understand the content of the classes as I would like). (As shown in Table 4).

In order to perform a reflection on the implications of mastery-avoidance goal, some classification parameters can be helpful. According to Elliot and McGregor (2001), this goal is classified as being more negative than the mastery-approach goal and more positive than the performance-approach goal. It is possible to state that the mastery-avoidance goal presents more negative characteristics than the mastery-approach goal, because as much as a student that is guided by this goal has as purpose the development and improvement of their skills and abilities, they also develop their motivation in order not to perceive themselves as incompetent.

Table 4

Overall descriptive analysis of the mastery-avoidance goal and AGQ items that make up this type of achievement goal

\begin{tabular}{|c|c|c|c|c|c|c|c|c|}
\hline Achievement Goals and Items & $\mathrm{N}$ & AVERAGE & S.D. & MIN & Q1 & MEDIAN & Q3 & MAX \\
\hline Mastery-avoidance Goal & 206 & 5.06 & 1.36 & 1.00 & 4.33 & 5.33 & 6.00 & 7.00 \\
\hline $\begin{array}{l}02 \text { - I am sometimes fearful } \\
\text { (afraid) of not being able to } \\
\text { understand the content of the } \\
\text { classes as I would like }\end{array}$ & 207 & 4.61 & 2.09 & 1.00 & 3.00 & 5.00 & 6.00 & 7.00 \\
\hline $\begin{array}{l}07 \text { - I often worry that I } \\
\text { cannot learn everything there is } \\
\text { to learn in the classroom. }\end{array}$ & 206 & 5.17 & 1.69 & 1.00 & 5.00 & 6.00 & 6.00 & 7.00 \\
\hline $\begin{array}{l}12 \text { - I worry that I cannot learn } \\
\text { all that I could in the classroom }\end{array}$ & 207 & 5.40 & 1.67 & 1.00 & 5.00 & 6.00 & 7.00 & 7.00 \\
\hline
\end{tabular}


Table 5

Overall descriptive analysis of the performance-approach goal and AGQ items that make up this type of achievement goal

\begin{tabular}{|c|c|c|c|c|c|c|c|c|}
\hline Achievement Goals and Items & $\mathrm{N}$ & AVERAGE & S.D. & MIN & Q1 & MEDIAN & Q3 & MAX \\
\hline Performance-approach Goal & 205 & 4.79 & 1.52 & 1.00 & 3.67 & 5.00 & 6.00 & 7.00 \\
\hline $\begin{array}{l}01 \text { - It is important for me to } \\
\text { do better than other students } \\
\text { of this class }\end{array}$ & 207 & 4.68 & 1.76 & 1.00 & 4.00 & 5.00 & 6.00 & 7.00 \\
\hline $\begin{array}{l}05 \text { - It is important for me to } \\
\text { perform well compared to the } \\
\text { rest of my classmates }\end{array}$ & 206 & 4.95 & 1.89 & 1.00 & 4.00 & 5.00 & 7.00 & 7.00 \\
\hline $\begin{array}{l}10-\text { My goal in this classroom } \\
\text { is to get better grades than } \\
\text { most students }\end{array}$ & 206 & 4.72 & 1.96 & 1.00 & 3.00 & 5.00 & 6.00 & 7.00 \\
\hline
\end{tabular}

Therefore, this kind of motivational profile can present a not so adaptative nature.

Other characteristics are also associated to the mastery-avoidance goal, as some prior results: fear of failure, low self-determination, low perception of engagement in class, etc. Also, some of the consequences regarding this type achievement goal can be mentioned, such as disorganization to study, anxiety, worry, etc. (Elliot \& McGregor, 2001). For these reasons, the mastery-avoidance goal presents a motivational profile as being not so adaptative when compared to mastery-approach goal.

Considering the characteristics presented above, it is necessary to emphasize the importance of positive feedback from the teacher to strengthen the students' beliefs, and to work as a protection factor when facing those risk factors mentioned in the previous paragraph. For instance, a student who shows interest in developing their learning, but due to the fear of failure or a low self-determination - especially in facing adversity may have this pattern of beliefs optimized by a teacher intervention that seeks to develop a positive bonding seeking to highlight, through positive feedback, the improvements this student may have.

The achievement goal that had lower adoption tendency was the performance-approach goal. As noted in Table 5, the item that showed the highest average score (4.95) was item five (It is important for me to perform well compared to the rest of my classmates). However, the item in which the average variation was bigger was in number ten (2.76 to 6.68 - My goal in this classroom is to get better grades than most students). On the other hand, the item that presented both the lowest average score (4.68) and the lowest average variation (2.92 to 6.44) was item one (It is important for me to do better than other students of this class). Regarding performance-approach goal, the average score was between 3.27 and 6.31 .

Although some authors have stated that performance goal standards are not very adaptative, others, like Pintrich (2000), show that in some situations, specifically when associated to mastery goal, the performance-approach goal may not be as maladaptative, and may result in better performance and achievement.

This topic aimed to present the results of this study as well as to discuss them in order to draw conclusions in the light of bibliography. It is worth highlighting that these results should not be seen as the division of achievement goals were symmetrically as presented. Such a division exposes tendencies in which students are guided to behave and establish their goals to perform in school activities, and the student may not have presented a high or low score in only one of the four achievement goals investigated. However, this study was not aimed at investigating the adoption of multiple goals, in which more than one achievement goal can be adopted.

\section{Final Considerations}

As shown previously, each achievement goal has different characteristics from each other, and from the tendency to adopt those is possible to verify many aspects, including the motivational question. However, the study of achievement goals should always take into 
account the contextual characteristics by which it is investigated, since similar results in different contexts may imply on other considerations.

Thus, high school in Brazil has unique characteristics that differ this level from others. One consideration is that this step has a transitional role for being the last stage of basic education and prior to insertion in higher education. Due to this fact, the representation that the college entrance examination acquires in many high school students' lives can be very significant, what may have an influence on the type of achievement goal adopted by students at this stage.

In qualitative terms, the mastery-approach goal, with the highest score average, may reveal that, although researches have pointed out how low motivation level of high school students can be, on the other hand, this result can prove the importance that these young people attach to study in their lives, even though this importance is associated with some kind of social mobility. Regarding the performance-avoidance goal (second largest average score presented), although the college entrance examination may acquire a high degree of significance in the lives of young people, what might result in a competitive environment that promotes actions to receive a positive judgement in relation to the grade obtained in this examination, the motivational quality of this goal can also be associated with the importance that the social judgment presents in adolescence.

Nevertheless, it is possible to point out some limitations of this study, for example, the fact that the mastery-approach goal has presented the highest adoption trend may have been influenced by the bias of self-presentation, typical of studies that use self-report questionnaires. The low consistency (Cronbach's alpha) of two subscales should be considered, and caution is needed when drawing conclusions. Such results may suggest the need for constant checking of the formulation and / or validation of instruments in terms of the context in which it is applied, since the validation by Gouveia et al. (2008) took place in a reality, at least in some ways, different from the contextual reality of this study.

Another limitation, that at the same time opens space for future researches, refers to the fact that this study did not concentrate their achievement of goals analysis in terms of students' period and school year. This information - period and school year - could allow a more specific look at the contextual factors that would be influencing the adoption of the achievement goals by students. Just as an indicative, most of the sample of the present study focused on the third year of high school and at the night period.

Also as a future direction, studies that seek to describe the adoption of achievement goals in high school under a gender perspective may have more parameters to understand this construct at this stage of education in Brazil. Another suggestion is carrying out studies on the achievement goals with students from private schools, given that in this study almost all of the participants were from public schools.

In summary, the study of achievement goals can be useful not only to classify behavioral tendencies or to differ students from the goals they have adopted. The contributions of this reflection insert the achievement goals as an important attribute to investigate the quality of the student's motivation as well as the factors that they are in charge. The analysis of the implicit motivational quality in achievement goals can function as an important model collaborating so that teachers and school agents understand the issues involved in the engagement purposes of students during tasks and activities in the school context, helping them in one of the noblest tasks of education: to contribute with the complete development of the subject.

\section{References}

Abramovay, M., \& Castro, M. G. (Orgs.). (2003). Ensino Médio: Múltiplas Vozes. Brasília: MEC, UNESCO.

Ames, C., Archer, J. (1988). Achievement Goals in the Classroom: Students` Learning Strategies and Motivation Process. Journal of Educational Psychology, 80(3), 260-267.

Amparo, D. M., Galvão, A. C. T., Cardenas, C., Koller, S. H. (2008). A escola e as perspectivas educacionais de jovens em situação de risco. Revista da ABRAPEE, 12(1), 69-88.

Boruchovitch, E., \& Bzuneck, J. A. (2010). Motivação para aprender no Brasil: estado da arte e caminhos futuros. Em E. Boruchovitch, J. A. Bzuneck, \& S. E. R. Guimarães, (Orgs.) Motivação para Aprender: aplicaşões no contexto educativo. (pp. 231-250). Petrópolis: Vozes.

Brasil, (1996). Lei no 9.394, de 20 de dezembro de 1996. Estabelece as Diretrizes e Bases da Educação Nacional. Diário Oficial da União. Brasília, no 248, 23/12/1996. 
Bzuneck, J. A. (2009a). A motivação do aluno: Aspectos Introdutórios. Em E. Boruchovitch, \& J. A. Bzuneck. A motivação do aluno: contribuições da psicologia contemporânea. (4 ed., pp. 9-36). Petrópolis: Vozes.

Bzuneck, J. A. (2009b). A motivação do aluno orientado a metas de realização. Em E. Boru- chovitch, \& J. A. Bzuneck. A motivação do aluno: contribuições da psicologia contemporânea. (4 ed., pp. 58-77). Petrópolis: Vozes.

Castro, C. M.. (2008). O Ensino Médio: órfão de idéias, herdeiro de equívocos. Ensaio: aval. pol. públ. Educ., 16(58), 113-124.

Costa, E. R., Boruchovitch, E. (2006). A Auto-eficácia e a Motivação para Aprender: conside- rações para o desempenho escolar dos aluno. Em R. G. Azzi, \& S. A. J. Polydoro (orgs). Auto-eficácia em diferentes contextos. (pp. 87-109). Campinas: Alínea.

Diener, C. I., Dweck C. S (1978). An analysis of learned helplessness: Continuous changes in performance, strategy, and achievement cognitions following failure. Journal of Personality and Social Psychology, 36, 451-462.

Dweck, C. S. (1975). The role of expectations and attribuitions in the alleviation of learned helplessness. Journal of Personality and Social Psychology, 31, 674-685.

Dweck, C. S., Leggett, E. L. (1988). A Social-Cognitive Approach to Motivation and Personality. Psychological Review, 95(2), 256-273.

Dweck, C. S., Reppucci, N. D. (1973). Learned helplessness and reinforcement responsibility in children. Journal of Personality and Social Psychology, 25, 109-116.

Elliot, A. J. (2005). A Conceptual History of the Achievement of Goal Construct. Em A. J. Elliot, \& C. S. Dweck. Handbook of Competences and Motivation. (pp. 52-72). New York: The Guilford Press.

Elliot, E. S., Dweck, C. S. (1988). Goals: An approach to motivation and achievement. Journal of Personality and Social Psychology, 54, 5-12, 1988.

Elliot, A. J., Mcgregor, H. A. (2001). A 2 x 2 achievement goals framework. Journal of Personality and Social Psychology, 80, 501-519.

Elliot, A. J., Mcgregor, H. A., Gable, S. (1999). Achievement goals, study strategies, and exam performance: A mediational analysis. Journal of Educational Psychology, 91, 549-563.

Elliot, A. J., Church, M. (1997). A hierarchical model of approach and avoidance achievement motivation. Journal of Personality and Social Psychology, 72, 218-232.

Elliot, A. J., Harachiewickz, J. M. (1996). Approach and avoidance achievement goals and intrinsic motivation: a meditational analysis. Journal of Personality and Social Psychology, 70, 461-475.

Fagundes, P. R., Aquino, M. G., Paula, A. V. (2010). Pré-vestibulandos: percepção do estress em jovens formandos do ensino médio. Akrópolis Umuarama, 18(1), 57-69.

Farrell, E., Dweck, C. S. (1985). The role of motivation processes in transfer of learning. Unpublished Manuscript.

Franco, M. L. P. B., Novaes, G. T. F. (2001). Os Jovens do Ensino Médio e suas representações Sociais. Cadernos de Pesquisa, (112), 167-183.

Gouveia, V. V., Diniz, P. K. C., Santos, W. S., Gouveia, R. S. V., Cavalcanti, J. P. N. (2008). Metas de realização entre estudantes do ensino médio: evidências de validade fatorial e consistência interna de uma medida. Psicologia: Teoria e Pesquisa, 24(4), 535-544.

Krawczyk, N. (2009). O Ensino Médio no Brasil. São Paulo: Ação Educativa.

Leggett, E.L., Dweck, C.S. (1986). Goals and inference rules: Sources of causal judgements, Manuscript submitted for publication. 1986.

Machado, N. M. L. (2005). A escola ideal: como os adolescentes percebem e idealizam o meio escolar. (Dissertação de Mestrado em Educação, Universidade Estadual de Campinas, Campinas, 2005).

Mello, G. N. (1998). As novas diretrizes para o ensino médio. São Paulo: CIEE.

Midgley, C., Kaplan, A., Middleton, M., Maehr, M. L., Urdan, T., Hicks Anderman, L., Anderman, E., Roeser, R. (1998). The development and validation of scales assessing students' achievement goal orientations. Contemporary Educational Psychology, 23, 113-131.

Pintrich, P. R. (2000). Multiple Goals, Multiple Pathways: The Role of Goal Orientation in Learning 
and Achievement. Journal of Educational Psychology, 92(3), 544-555.

Rodrigues, D. G., Pelisoli, C. (2008). Ansiedade em vestibulandos: um estudo exploratório. Revista de Psiquiatria Clínica, 35, 171-177.

Shim, S. S., Ryam, A. M., Anderson, C. J. (2008). Achievement Goals and Achievement During Early Adolescence: Examining Time-Varying Predictor and Outcome Variables in Growth-Curve Analysis. Journal of Educational Psychology, 100(3), 655-671.

Valle, A., Cabanach, R. G., Nuñez, J. C., González-Pienda, J., Rodríguez, S., Piñeiro, I. (2003). Multiple goals, motivation and academic learning. British Journal of Educational Psychology, 73, 71-87.

Wigfield, A., Cambria, J. (2010). Students' achievement values, goal orientations, and interest: Definitions, development, and relations to achievement outcomes. Developmental Review, 30, 1-35.

Zeronini, R. P. C., \& Santos, A. A. A. (2010). Teoria de metas de realização: Fundamentos e Avaliação. Em E. Boruchovitch, J. A. Bzuneck, \& S. E. R. Guimarães (Orgs.). Motivação para aprender: Aplicações no contexto educativo. (pp. 99-125). Petrópolis: Vozes.

Recebido em: 15/12/2014

Reformulado em: 20/04/2015

Aprovado em: 03/07/2015

Acknoledgments

To CAPES, to Group NEAPSI and, especially to professor Dra. Roberta Gurgel Azzi, for whom the author demonstrates enormous gratitude.

Sobre o autor:

Marcelo Simões Mendes é psicólogo, educador físico, mestre em Educação pela Faculdade de Educação da Unicamp, professor do curso de Psicologia da Universidade Paulista (UNIP/Campinas), da Pontifícia Universidade Católica de Campinas (PUCCAMP) e do Curso de Pós-graduação de Psicopedagogia na Educação da UNIP/Campinas.

E-mail:m_smendes@yahoo.com.br

Contato com o autor:

Av. Comendador Enzo Ferrari, 280 - Swift

CEP: 13043-900

Campinas-SP, Brasil

Psico-USF, Bragança Paulista, v. 21, n. 2, p. 353-366, mai./ago. 2016 
